\title{
Trihalomethanes in Water Supply System and Water Distribution Networks
}

\author{
Sornsiri Sriboonnak 1,2, Phacharapol Induvesa ${ }^{3}$, Suraphong Wattanachira ${ }^{4}$, Pharkphum Rakruam ${ }^{4}$, \\ Adisak Siyasukh ${ }^{5}$, Chayakorn Pumas ${ }^{6,7}$ (D), Aunnop Wongrueng $4,7,8, * \mathbb{D}$ and Eakalak Khan 9 (D)
}

1 Ph.D.'s Degree Program in Environmental Engineering, Faculty of Engineering, Chiang Mai University, Chiang Mai 50200, Thailand; sornsiri_sri@cmu.ac.th

2 Graduate School, Chiang Mai University, Chiang Mai 50200, Thailand

3 Bodhivijjalaya College, Srinakharinwirot University, Nakhon Nayok 26120, Thailand; phacharapol@g.swu.ac.th

4 Department of Environmental Engineering, Faculty of Engineering, Chiang Mai University, Chiang Mai 50200, Thailand; suraphong@eng.cmu.ac.th (S.W.); pharkphum@eng.cmu.ac.th (P.R.)

5 Department of Industrial Chemistry, Faculty of Science, Chiang Mai University, Chiang Mai 50200, Thailand; adisak.si@cmu.ac.th

6 Department of Biology, Faculty of Science, Chiang Mai University, Chiang Mai 50200, Thailand; chayakorn.pumas@gmail.com

7 Research Center in Bioresources for Agriculture, Industry and Medicine, Chiang Mai University, Chiang Mai 50200, Thailand

8 Research Program in Control of Hazardous Contaminants in Raw Water Resources for Water Scarcity Resilience, Center of Excellence on Hazardous Substance Management, Bangkok 10330, Thailand

check for updates

Citation: Sriboonnak, S.; Induvesa, P.; Wattanachira, S.; Rakruam, P.; Siyasukh, A.; Pumas, C.; Wongrueng, A.; Khan, E. Trihalomethanes in Water Supply System and Water Distribution Networks. Int. J. Environ. Res. Public Health 2021, 18, 9066. https://doi.org/10.3390/ijerph 18179066

Academic Editor: Paul B. Tchounwou

Received: 22 July 2021

Accepted: 25 August 2021

Published: 27 August 2021

Publisher's Note: MDPI stays neutral with regard to jurisdictional claims in published maps and institutional affiliations.

Copyright: (c) 2021 by the authors. Licensee MDPI, Basel, Switzerland. This article is an open access article distributed under the terms and conditions of the Creative Commons Attribution (CC BY) license (https:// creativecommons.org/licenses/by/ $4.0 /)$
9 Department of Civil and Environmental Engineering and Construction, University of Nevada, Las Vegas, NV 89154, USA; eakalak.khan@unlv.edu

* Correspondence: aunnop@eng.cmu.ac.th; Tel.: +66-53-94-4101-3

Abstract: The formation of trihalomethanes (THMs) in natural and treated water from water supply systems is an urgent research area due to the carcinogenic risk they pose. Seasonal effects and $\mathrm{pH}$ have captured interest as potential factors affecting THM formation in the water supply and distribution systems. We investigated THM occurrence in the water supply chain, including raw and treated water from water treatment plants (coagulation, sedimentation, sand filtration, $\mathrm{ClO}_{2}$-disinfection processes, and distribution pipelines) in the Chiang Mai municipality, particularly the educational institute area. The effects of two seasons, rainy (September-November 2019) and dry (December 2019-February 2020), acted as surrogates for the water quality profile and THM occurrence. The results showed that humic acid was the main aromatic and organic compound in all the water samples. In the raw water sample, we found a correlation between surrogate organic compounds, including SUVA and dissolved organic carbon (DOC) $\left(\mathrm{R}^{2}=0.9878\right)$. Four species of THMs were detected, including chloroform, bromodichloromethane, dibromochloromethane, and bromoform. Chloroform was the dominant species among the THMs. The highest concentration of total THMs was $189.52 \mu \mathrm{g} / \mathrm{L}$. The concentration of THMs tended to increase after chlorination when chlorine dioxide and organic compounds reacted in water. The effect of $\mathrm{pH}$ on the formation of TTHMs was also indicated during the study. TTHM concentrations trended lower with a $\mathrm{pH} \leq 7$ than with a $\mathrm{pH} \geq 8$ during the sampling periods. Finally, in terms of health concerns, the concentration of TTHMs was considered safe for consumption because it was below the standard $(<1.0)$ of WHO's Guideline Values (GVs).

Keywords: disinfection byproducts; distribution networks; trihalomethanes

\section{Introduction}

Water supply systems are essential to the inhabitants of Chiang Mai Province, Thailand, and the rest of the world. At present, Thailand has a population of 66.19 million people, a growth of 1.01-fold in the past five years [1]. As a result, the demand for water 
consumption has increased 1.16-fold in this period (from 1835.1 million $\mathrm{m}^{3}$ in 2015 to 2121.1 million $\mathrm{m}^{3}$ in 2020) [2]. In general, the water supply system consists of coagulation and flocculation, sedimentation, and sand filtration, followed by disinfection, before being pumped through the water distribution networks. The sedimentation and sand filtration processes are highly effective in removing suspended solids and turbidity [3]. However, dissolved organic matter (DOM), which comprises molecules smaller than $0.45 \mu \mathrm{m}$, i.e., dissolved organic carbon (DOC), humic acid, and fulvic acid, cannot be effectively removed from the sand filter tank [4]. The most common disinfectants used in the disinfection process are chlorine, chloramines, ozone, and chlorine dioxide [5]. These substances react with DOM, forming disinfectant byproducts (DBPs) that include mutagenic and carcinogenic substances [6-8]. There are many types of DBPs, including trihalomethanes (THMs), haloacetic acids (HAAs), and haloacetonitriles (HANs) $[9,10]$. THMs, including chloroform (CF), bromodichloromethane (BDCM), dibromochloromethane (DBCM), and bromoform (BF), are the dominant DBP species detected in water supply systems [11-13]. Consumption of water contaminated with THMs over a long period increases the risk of bladder cancer [14]. Due to adverse health effects caused by DBPs, the World Health Organization (WHO) created guidelines for maximum allowable THMs levels [5]. In addition, the U.S. Environmental Protection Agency (USEPA) states that the maximum contamination level for the four THMs mentioned above is $80 \mu \mathrm{g} / \mathrm{L}$. In Thailand, water authorities adopted these guidelines to regulate CF, BDCM, DBCM, and BF, with Guideline Values (GVs) of $300,60,100$, and $100 \mu \mathrm{g} / \mathrm{L}$, respectively. The sum of the ratios of THMs to their respective GV must be less than one [5]. In addition, iodinated DBPs, such as iodinated THMs, were detected. Ackerson et al. [15] reported that the occurrence of six iodinated THMs (I-THMs; iodoform (TIM), bromodiiodomethane (BDIM), dibromoiodomethane (DBIM), dichloroiodomethane (DCIM), chlorodiiodomethane (CDIM), and chlorobromomethane (CBIM)) was caused by the formation of hypoiodous acid (HOI) during the treatment process. These DBPs are more genetically toxic and cytotoxic than regulated DBPs, including chlorinated and bromine-containing DBPs [16,17]. Many factors have been considered in predicting and controlling DBPs formation, including DOC, ultraviolet absorbance at a wavelength of $254 \mathrm{~nm}$ (UV-254), $\mathrm{pH}$, temperature, alkalinity, reaction time, and bromide ions, which strongly impact the distribution of the compounds among the four THM species and may affect reaction yields. Higher THM concentrations generally predict higher levels of the factors mentioned [18-20]. The chemical and physical properties of disinfectants and DBPs affect their behavior in drinking water [21-24]. Ratpukdi et al. [25] showed that high DOC values in water distribution networks from the Khon Kaen Municipality, Thailand, were related to THMs. The highest amounts of THMs and HANs were 584 and $30 \mu \mathrm{g} / \mathrm{L}$, respectively. Ratpukdi et al.'s study created our concern about DBPs in the water distribution network and water supply system of an educational institute in Chiang Mai Province, Thailand.

In this study, we investigated the seasonal (rainy and dry seasons) concentration of trihalomethanes (THMs) in the water supply system and water distribution networks of an educational institute in Chiang Mai Province, Thailand. The water supply system used chlorine dioxide $\left(\mathrm{ClO}_{2}\right)$ as a disinfectant. The research was performed from September 2019 to February 2020. Other water parameters, including temperature, pH, alkalinity, electrical conductivity, dissolved organic carbon, UV-254 absorbance, and fluorescence excitation-emission matrix (FEEM) measurements, were also conducted.

\section{Materials and Methods}

\subsection{Water Supply System and Distribution Networks}

We examined the water quality of a water supply system located in an educational institute in Chiang Mai, Thailand, that has a capacity of $8000 \mathrm{~m}^{3} / \mathrm{d}$ (Figure 1). The water supply system comprises raw water intake, a coagulation and flocculation unit, sedimentation tank, sand filtration, chlorination tank, and storage tank. The water distribution networks supply water to all buildings and facilities in the educational institute. 


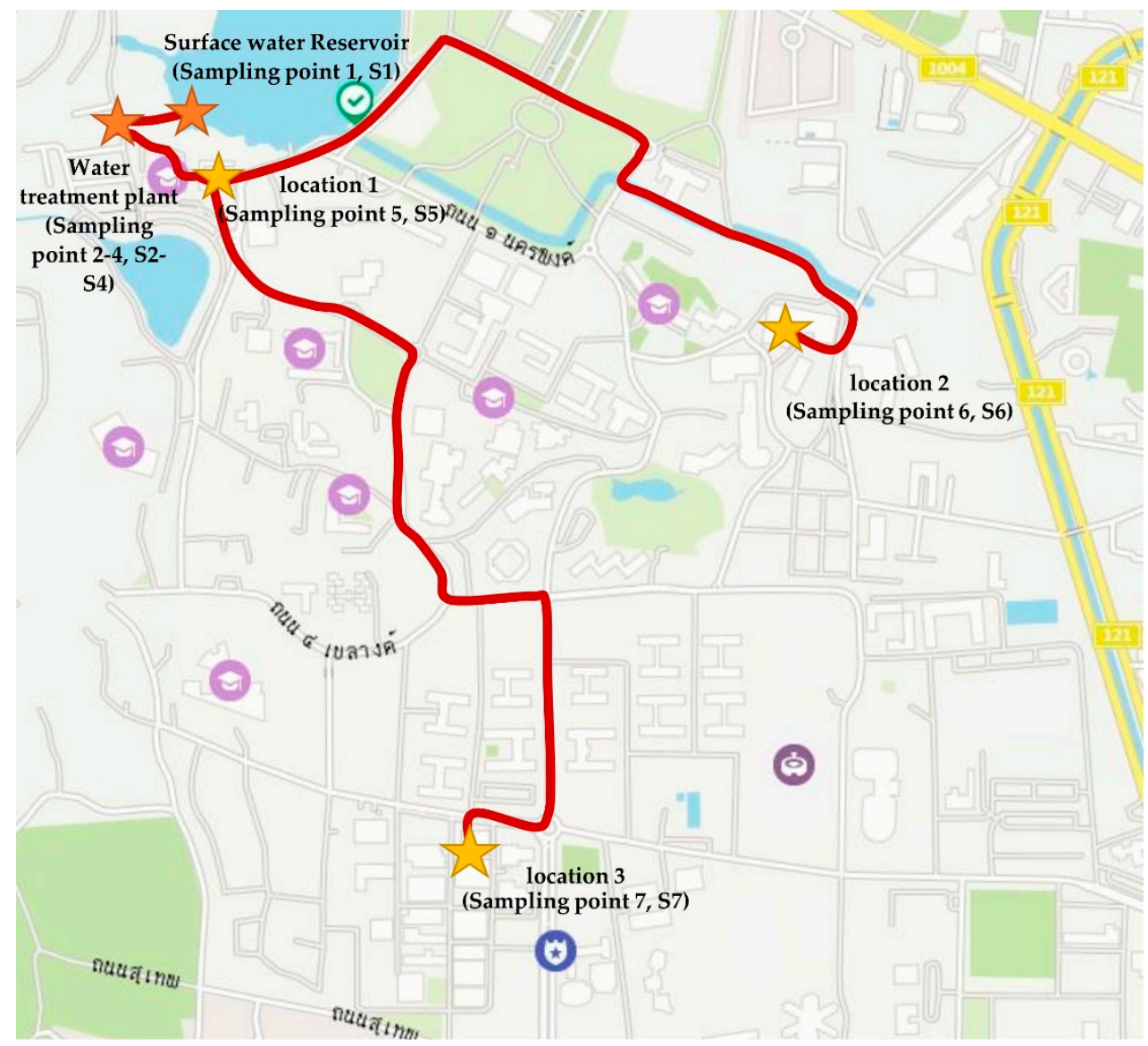

Figure 1. Sampling locations [26].

\subsection{Sampling Locations}

Seven sampling points were chosen to assess the water quality of the distribution systems. In the water supply system, four sampling points-raw water (surface water), sedimentation tank, chlorination tank $\left(\mathrm{ClO}_{2}\right.$ disinfection), and storage tank-were selected, as shown in Figure 2. The other three sampling points were spread throughout the distribution lines. Information on sampling location is reported in Table 1.

Table 1. Information on sampling locations.

\begin{tabular}{|c|c|c|c|c|}
\hline Distribution System & $\begin{array}{l}\text { Sampling } \\
\text { Point }\end{array}$ & $\begin{array}{l}\text { Distance from Water } \\
\text { Treatment Plant }(\mathrm{km})\end{array}$ & Coordinates & $\begin{array}{l}\text { Information on } \\
\text { Sampling Location }\end{array}$ \\
\hline surface water reservoir & S1 & 0.20 & $18^{\circ} 48^{\prime} 23.4^{\prime \prime} \mathrm{N} 98^{\circ} 56^{\prime} 59.0^{\prime \prime} \mathrm{E}$ & surface water \\
\hline water treatment plant & S2 & 0.00 & $18^{\circ} 48^{\prime} 19.5^{\prime \prime} \mathrm{N} 98^{\circ} 56^{\prime} 49.6^{\prime \prime} \mathrm{E}$ & sedimentation tank \\
\hline water treatment plant & S3 & 0.00 & $18^{\circ} 48^{\prime} 19.5^{\prime \prime} \mathrm{N} 98^{\circ} 56^{\prime} 49.6^{\prime \prime} \mathrm{E}$ & chlorination tank \\
\hline water treatment plant & S4 & 0.10 & $18^{\circ} 48^{\prime} 19.5^{\prime \prime} \mathrm{N} 98^{\circ} 56^{\prime} 49.6^{\prime \prime} \mathrm{E}$ & after chlorination tank \\
\hline location 1 & S5 & 0.13 & $18^{\circ} 48^{\prime} 17.2^{\prime \prime} \mathrm{N} 98^{\circ} 56^{\prime} 53.4^{\prime \prime} \mathrm{E}$ & - \\
\hline location 2 & S6 & 1.00 & $18^{\circ} 48^{\prime} 10.8^{\prime \prime} \mathrm{N} 98^{\circ} 57^{\prime} 25.0^{\prime \prime} \mathrm{E}$ & - \\
\hline location 3 & S7 & 1.13 & $18^{\circ} 47^{\prime} 45.3^{\prime \prime} \mathrm{N} 98^{\circ} 57^{\prime} 03.8^{\prime \prime} \mathrm{E}$ & - \\
\hline
\end{tabular}

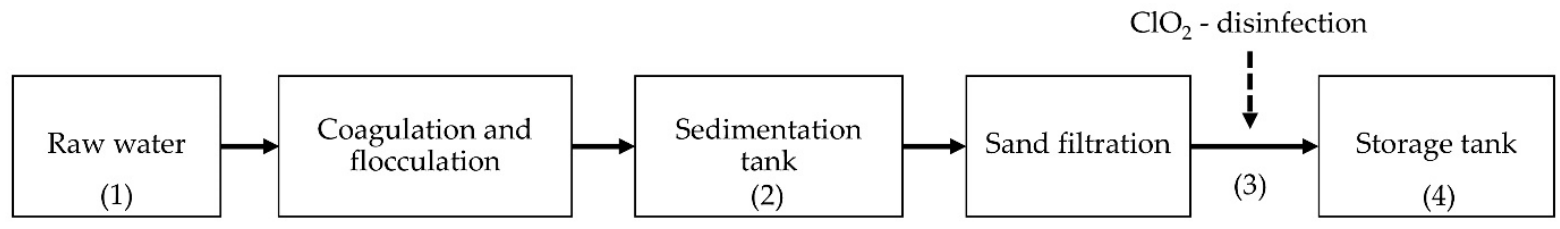

Figure 2. Sampling locations in the water supply system. 


\subsection{Sampling Plan}

The sampling period was divided into two seasons: rainy (September-November 2019) and dry (December 2019-February 2020). During each collection, five liters of water were sampled. Amber plastic bottles containing the water samples (without headspace) were stored in a dark refrigerator at $4{ }^{\circ} \mathrm{C}$ until the analysis.

\subsection{Analyses}

\subsubsection{Physical Parameters}

The $\mathrm{pH}$ level (PH60-E, Apera) and temperature of each water sample were measured at the time of collection. In addition, the samples were analyzed for electrical conductivity (SCHOTT, handy lab LF1).

\subsubsection{Chemical Analysis}

All samples were pre-filtered using a $0.7 \mu \mathrm{m}$ GF/F filter followed by a $0.45 \mu \mathrm{m}$ nylon membrane filter within an hour after collection. The samples were analyzed for $\mathrm{CaCO}_{3}$, representing alkalinity (titration method, Standard Method 2320B [27]). During titration, $0.0200 \mathrm{M}$ phosphoric acid was used along with methyl orange as an indicator. The alkalinity equivalent to carbonate was then calculated. DOC was measured by a TOC analyzer (TOC multi N/C 2100, Analytic Jena, Jena, Germany, Standard Method 5310). The ultraviolet absorbance of the sample at $254 \mathrm{~nm}$ (UV-254) was also determined using a UV/VIS spectrophotometer (Lambda 365, Perkin Elmer, Perkin Elmer Inc, Boston, MA, USA, Standard Method 5910B). Then, $5.00 \mathrm{~g}$ of sodium sulfate anhydrous was added to $25 \mathrm{~mL}$ of the sample solution in $40.00 \mathrm{~mL}$ amber vials to measure the amount of THMs. The solution was then vigorously stirred to obtain a homogenous solution. After that, $2.5 \mathrm{~mL}$ of methyl tertiary butyl ether (MTBE) solution was added and extracted for $3 \mathrm{~min}$. The top layer of MTBE was used for concentration analysis via a gas chromatograph (GC) equipped with an electron capture detector (GC-ECD) system (Agilent $4890 \mathrm{D}$ (EPA 551.1)). The GC column uses a VF-X fused silica capillary column $(30 \mathrm{~m} \times 0.32 \mathrm{~mm} \times 0.1 \mu \mathrm{m})$, and helium was used as a carrier gas [28]. Fluorescence excitation-emission matrices (FEEM) were analyzed to obtain the DOM characteristics of the water samples. The excitation wavelength started from $220 \mathrm{~nm}$ to $600 \mathrm{~nm}$ and increased by intervals of $5 \mathrm{~nm}$. FEEM spectroscopy was achieved using a spectrofluorometer (JASCO, FP-6200, JASCO international, Tokyo, Japan).

\section{Results}

\subsection{Physical Parameters}

The characteristics of all the samples in the water supply system are shown in Table 2. The water temperature, conductivity, and $\mathrm{pH}$ were $25.0-30.7^{\circ} \mathrm{C}, 130.1-187.7 \mu \mathrm{S} / \mathrm{cm}$, and 5.9-8.5, respectively.

Table 2. Water temperature, conductivity, and $\mathrm{pH}$ of water samples.

\begin{tabular}{|c|c|c|c|c|c|c|c|c|c|c|}
\hline \multirow{2}{*}{ Parameters } & \multirow{2}{*}{$\begin{array}{c}\text { WHO Acceptable } \\
\text { Value [5] }\end{array}$} & \multirow{2}{*}{\multicolumn{2}{|c|}{ Season/Month }} & \multicolumn{7}{|c|}{ Sampling Point } \\
\hline & & & & S1 & $\mathrm{S} 2$ & S3 & $\mathrm{S} 4$ & S5 & S6 & S7 \\
\hline \multirow{6}{*}{$\mathrm{pH}$} & \multirow{6}{*}{$6.5-8.5$} & \multirow{3}{*}{ rainy } & Sep & 8.5 & 7.1 & 6.8 & 7.5 & 7.5 & 7.5 & 7.4 \\
\hline & & & Oct & 7.8 & 6.9 & 5.9 & 7.1 & 7.4 & 6.5 & 7.6 \\
\hline & & & Nov & 6.6 & 6.5 & 6.1 & 7.0 & 6.3 & 6.5 & 6.5 \\
\hline & & \multirow{3}{*}{ dry } & Dec & 6.6 & 6.3 & 6.1 & 6.7 & 6.5 & 6.5 & 6.6 \\
\hline & & & Jan & 8.1 & 7.8 & 7.7 & 7.4 & 7.2 & 7.1 & 7.1 \\
\hline & & & Feb & 8.7 & 7.4 & 7.5 & 7.3 & 7.3 & 7.2 & 7.3 \\
\hline \multirow{6}{*}{$\begin{array}{l}\text { Water temperature } \\
\qquad\left({ }^{\circ} \mathrm{C}\right)\end{array}$} & \multirow{6}{*}{-} & \multirow{3}{*}{ rainy } & Sep & 30.7 & 28.7 & 29.0 & 38.7 & 28.0 & 28.0 & 28.0 \\
\hline & & & Oct & 30.0 & 28.5 & 28.2 & 26.3 & 28.0 & 28.5 & 28.0 \\
\hline & & & Nov & 29.7 & 28.2 & 27.8 & 28.0 & 26.1 & 26.5 & 25.0 \\
\hline & & \multirow{3}{*}{ dry } & Dec & 30.0 & 29.0 & 28.0 & 28.0 & 27.0 & 26.5 & 26.1 \\
\hline & & & Jan & 30.2 & 29.8 & 29.5 & 29.3 & 28.7 & 28.9 & 29.0 \\
\hline & & & Feb & 30.4 & 30.0 & 29.4 & 29.1 & 29.1 & 28.9 & 28.9 \\
\hline
\end{tabular}


Table 2. Cont.

\begin{tabular}{|c|c|c|c|c|c|c|c|c|c|c|}
\hline \multirow{2}{*}{ Parameters } & \multirow{2}{*}{$\begin{array}{c}\text { WHO Acceptable } \\
\text { Value [5] }\end{array}$} & \multirow{2}{*}{\multicolumn{2}{|c|}{ Season/Month }} & \multicolumn{7}{|c|}{ Sampling Point } \\
\hline & & & & S1 & S2 & S3 & $\mathrm{S} 4$ & S5 & S6 & S7 \\
\hline \multirow{6}{*}{$\begin{array}{l}\text { Electroconductivity } \\
\qquad(\mu \mathrm{S} / \mathrm{cm})\end{array}$} & \multirow{6}{*}{$<500$} & \multirow{3}{*}{ rainy } & Sep & 130.1 & 149.8 & 186.7 & 154.5 & 157.7 & 165.0 & 155.9 \\
\hline & & & Oct & 141.2 & 161.9 & 183.4 & 166.5 & 187.7 & 167.5 & 168.6 \\
\hline & & & Nov & 131.4 & 155.2 & 165.2 & 149.8 & 161.1 & 147.2 & 149.8 \\
\hline & & \multirow{3}{*}{ dry } & Dec & 181.7 & 193.9 & 287.1 & 274.9 & 259.0 & 230.8 & 254.1 \\
\hline & & & Jan & 170.0 & 172.7 & 188.8 & 194.7 & 184.1 & 185.7 & 186.9 \\
\hline & & & Feb & 174.9 & 190.6 & 208.3 & 197.8 & 212.5 & 200.4 & 191.0 \\
\hline
\end{tabular}

\subsection{Chemical Analysis}

3.2.1. Alkalinity, DOC, and UV-254 Absorbance

The results of the alkalinity, DOC, and UV-254 absorbance measurements are shown in Figures 3-5 and Table S1 of the Supplementary Materials, respectively.

The alkalinity values (Figure 3) during the rainy season were in the range of $20-40 \mathrm{mg} / \mathrm{L}$ of $\mathrm{CaCO}_{3}$. However, the value increased in the dry season with a range of $50-75 \mathrm{mg} / \mathrm{L}$ of $\mathrm{CaCO}_{3}$.

The DOC analysis of the water at various sampling points during the rainy and dry seasons is shown in Figure 4. In both seasons, the result shows that the DOC of the raw water sample from the surface water reservoir was approximately $4.0 \mathrm{mg} / \mathrm{L}$.

The UV-254 absorbance values measured in the raw water sample from the surface water reservoir were approximately $0.120 \mathrm{~cm}^{-1}$ and $0.080 \mathrm{~cm}^{-1}$ in the rainy and dry seasons, respectively. UV-254 absorbance decreased to approximately $0.030 \mathrm{~cm}^{-1}$ in both seasons after passing through water treatment units. The SUVA value of tap water collected each month (rainy and dry seasons) from different locations and the correlation between DOC and SUVA are shown in Table S2 and Figure S1 of the Supplementary Materials, respectively. The SUVA value range for raw water is $1.84-2.77 \mathrm{~L} / \mathrm{mg} \cdot \mathrm{m}$.

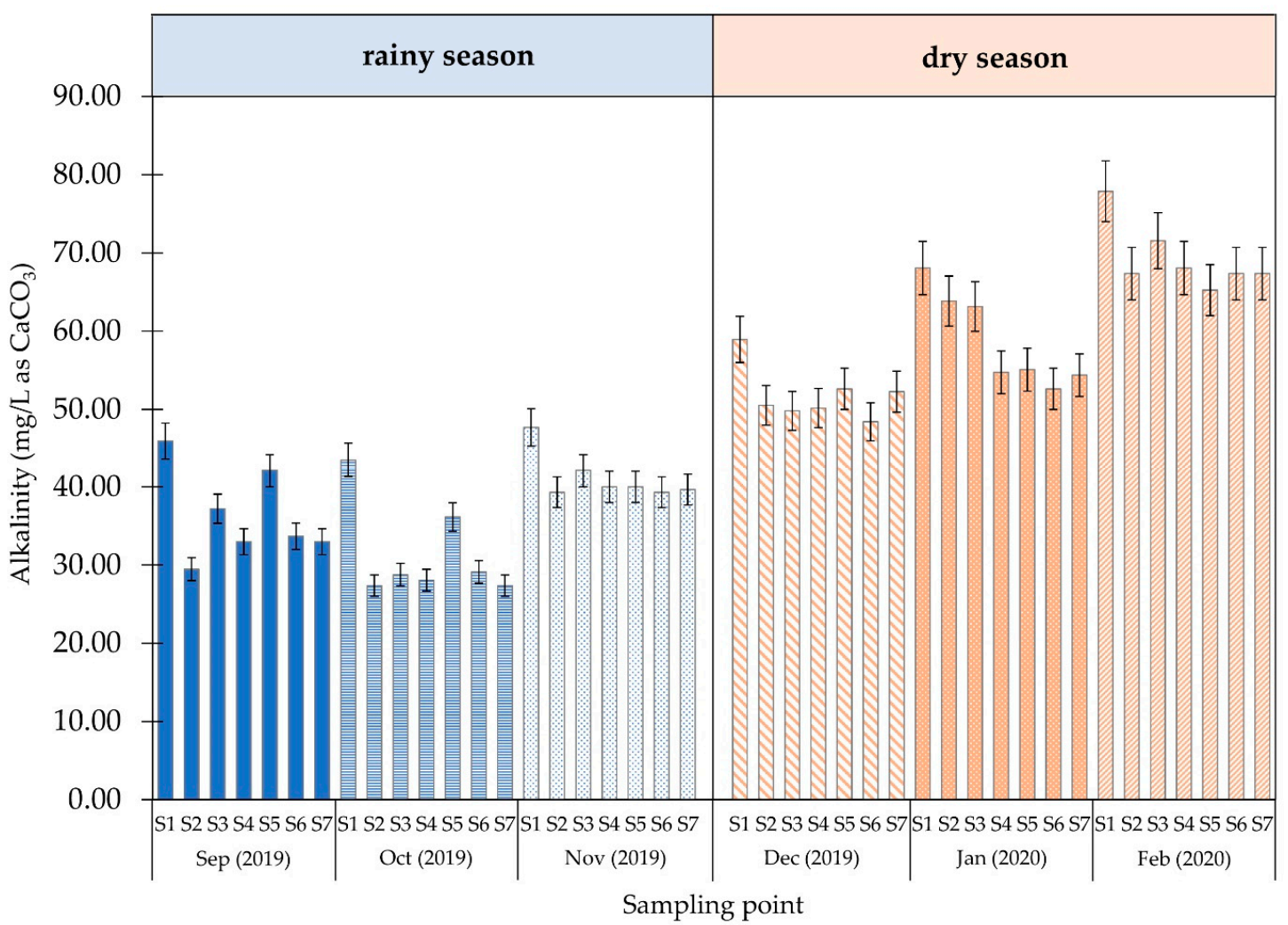

Figure 3. Alkalinity of water at each sampling point. 


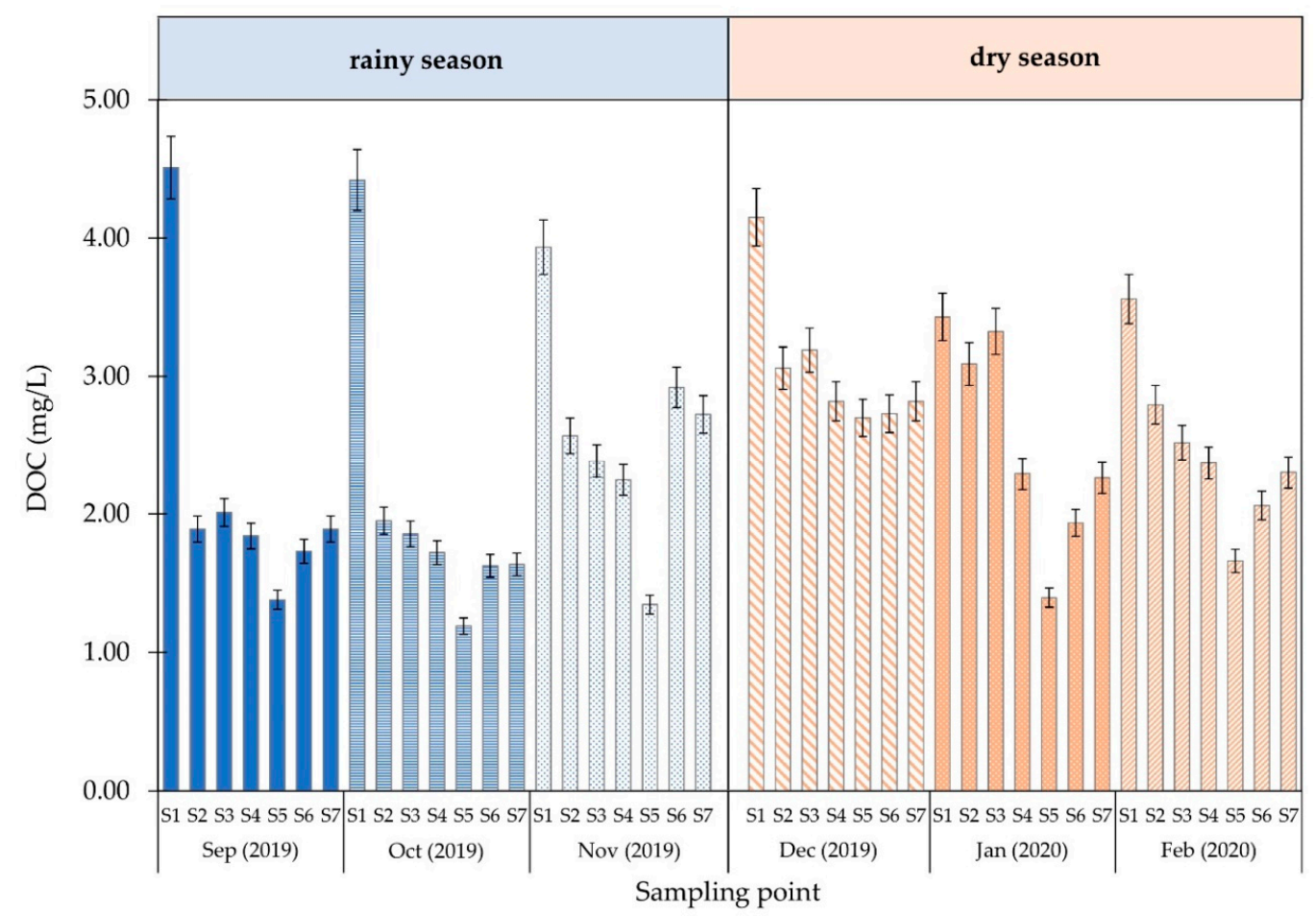

Figure 4. DOC of water at each sampling point.

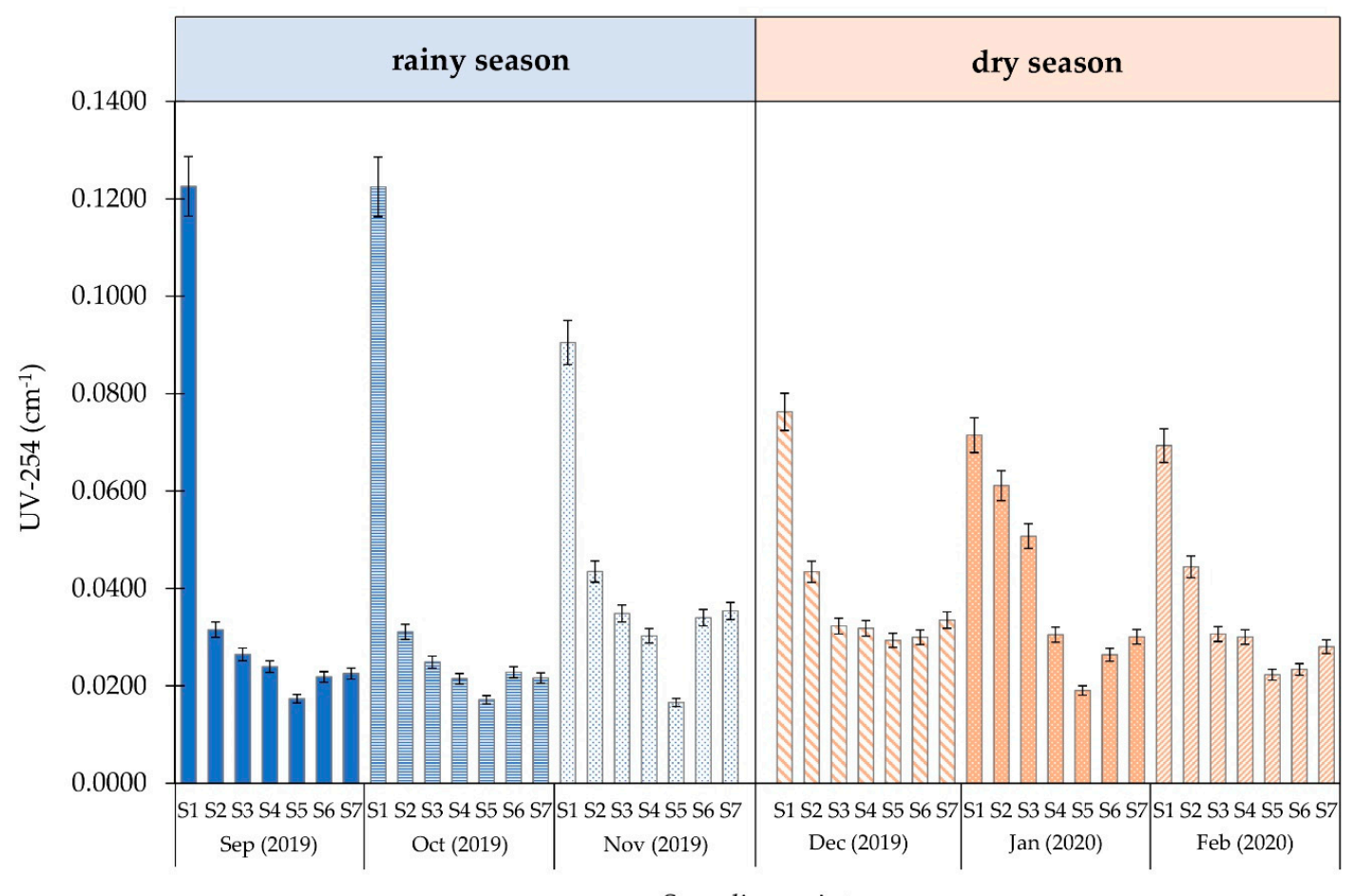

Sampling point

Figure 5. UV absorbance (UV-254) of water at each sampling point.

\subsubsection{FEEM}

The FEEM technique is a method for identifying natural organic substances, i.e., natural organic matter in water. FEEM peaks at positions $(E x / E m) 270 \mathrm{~nm} / 465 \mathrm{~nm}$, $270 \mathrm{~nm} / 470 \mathrm{~nm}, 275 \mathrm{~nm} / 490 \mathrm{~nm}, 270 \mathrm{~nm} / 465 \mathrm{~nm}, 275 \mathrm{~nm} / 485 \mathrm{~nm}$, and $270 \mathrm{~nm} / 465 \mathrm{~nm}$ in September, October, November, December, January, and February, respectively. The FEEM results are shown in Figure 6. 

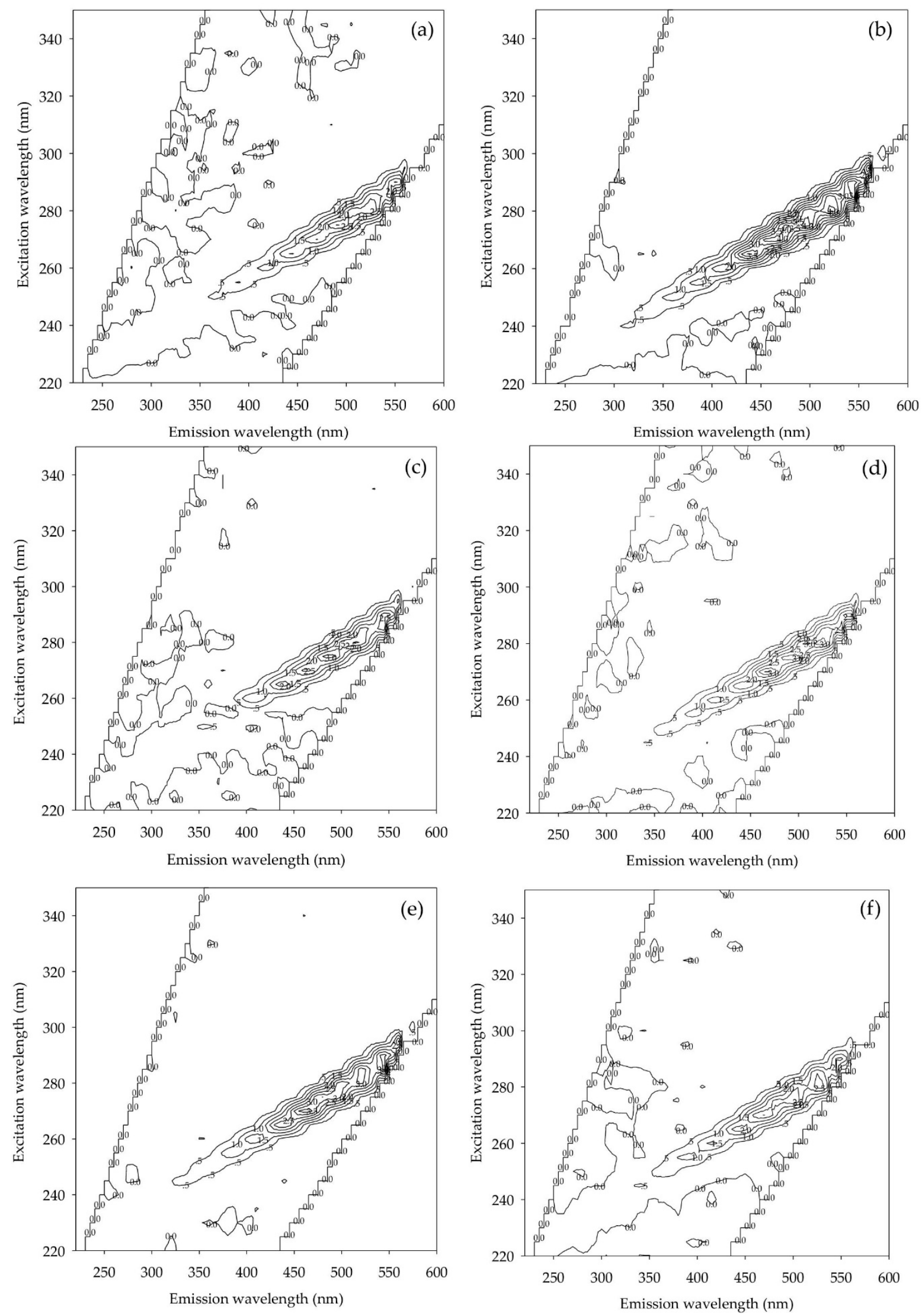

Figure 6. FEEM results of raw water, measured for six months: (a) September (2019), (b) October (2019), (c) November (2019), (d) December (2019), (e) January (2020), and (f) February (2020). 


\subsubsection{Occurrence of Total Trihalomethanes (TTHMs)}

The concentration of TTHMs in the water samples obtained from the sampling locations in Chiang Mai, Thailand, is shown in Figure 7 and the concentration of each THM species is shown in Figure S2 of the Supplementary Materials. The result showed that the water sample from sampling 1 (raw water) and sampling 2 (coagulation process) contained some TTHMs. The highest concentration of TTHMs was $189.52 \mu \mathrm{g} / \mathrm{L}$ at sampling point 3 . The sampling points 5-7 were approximately $60.00 \mu \mathrm{g} / \mathrm{L}$ for both seasons.

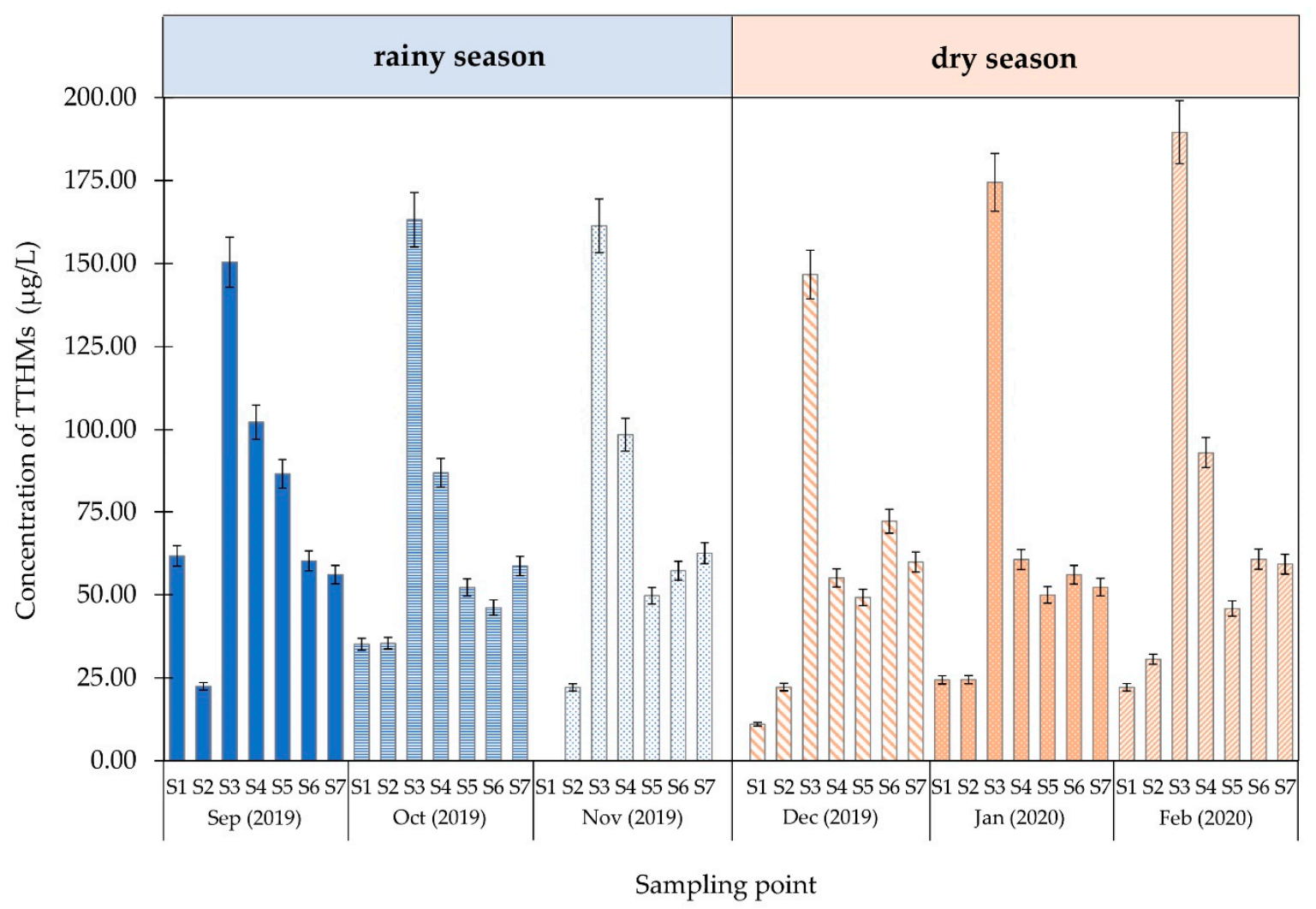

Figure 7. TTHM concentration of water in Chiang Mai, Thailand.

\section{Discussion}

Regarding the physical parameters of the water profile, the highest $\mathrm{pH}$ value was 8.5 for the rainy season and 8.7 for the dry season. The highest temperatures were $30.4{ }^{\circ} \mathrm{C}$ and $30.7^{\circ} \mathrm{C}$ in the rainy and dry seasons, respectively. However, the conductivity was highest at $287.1 \mu \mathrm{S} / \mathrm{cm}$ in the dry season and $187.7 \mu \mathrm{S} / \mathrm{cm}$ in the rainy season. The water temperature and $\mathrm{pH}$ did not vary to any significant degree according to these results. Regardless, the electrical conductivity was lower than the water standard [5].

The highest alkalinity value was $78 \mathrm{mg} / \mathrm{L}$ of $\mathrm{CaCO}_{3}$ at sampling point 1 , measured in February 2020. Compared with the surface water, the water at sampling point 1 underwent sedimentation, resulting in lower alkalinity. The alkalinity decreased from $45 \mathrm{mg} / \mathrm{L}$ to $30 \mathrm{mg} / \mathrm{L}$ of $\mathrm{CaCO}_{3}$ during the rainy season from 70 to $60 \mathrm{mg} / \mathrm{L}$ of $\mathrm{CaCO}_{3}$ during the dry season. The lower alkalinity value was due to the formation of sediments from using coagulants.

The DOC index analysis was based on the DOC and UV-254 water measurements at each sampling point during the rainy and dry seasons. The increased DOC values for both seasons were comparable to raw water from an alternative tap water source in Thailand. The DOC decreased to approximately $2.0 \mathrm{mg} / \mathrm{L}$ in both seasons after passing through the water treatment units. DOC significantly decreased from $9.91 \%$ to 58.09 during the rainy season, indicating that the water treatment units removed some organic matter. 
Monthly changes in the organic content of raw water indicated that the water quality was superior during the rainy season when the organic content was lower. In the rainy season, water turbidity was caused by rain and more organic matter leached from the soil into the stream. Tungsudjawong et al. [29] reported that the Chao Phraya River had more DOC during the rainy season than the dry season. Based on the UV-254 measurement definitions, organic matter containing aromatic clusters and double-bond molecules absorb UV light at a wavelength of $254 \mathrm{~nm}[30,31]$. The obtained UV-254 results showed that the absorbance decreased by approximately $74.63 \%$. In addition, the low absorbance at $254 \mathrm{~nm}$ implied that the water from each sampling location contained a small amount of aromatic and double-bond organic compounds. The specific ultraviolet absorption (SUVA) index combines the UV-254 absorbance value and the DOC using a calculation dividing the UV-254 by the DOC and multiplying it by 100 . The resulting SUVA value was used to indicate the appropriate type of treatment process for DOMs in water [32]. A SUVA value $<2 \mathrm{~L} / \mathrm{mg} \cdot \mathrm{m}$ generally indicates that the sample water contains aliphatic hydrocarbons [33]. ASUVA value $>2 \mathrm{mg} / \mathrm{L}$ may consist of aromatic hydrocarbon. SUVA value increased during the rainy season compared with the dry season, and the average SUVA $(2.60 \mathrm{~L} / \mathrm{mg} \cdot \mathrm{m})$ was $>2 \mathrm{~L} / \mathrm{mg} \cdot \mathrm{m}$ due to the leaching of organic matter into raw water during the rainy season. This was also found for water with a higher ratio of double bonds. This substance may be moderately relevant to THM formation [34].

No significant change occurred in the spectrum peaks of FEEM spectra (Figure 6) for six months. Chen et al. [35] described the extent of excitation (Ex) and emission (Em) wavelengths according to five sections or "Regions": In Region 1, Ex/Em values range from 220-250 nm/280-330 nm, representing tyrosine or aromatic proteins. In Region 2, Ex/Em values range from $220-250 \mathrm{~nm} / 330-380 \mathrm{~nm}$, representing $\mathrm{BOD}_{5}$ or aromatic proteins. In Region 3, Ex/Em values are $220-250 \mathrm{~nm} />380 \mathrm{~nm}$, representing hydrophobic acids or fluvic-acid-like substances. In Region 4, Ex/Em values are $>250 \mathrm{~nm} / 280-330 \mathrm{~nm}$ and represent soluble microbial byproduct-like substances. Finally, in Region 5, Ex/Em values are $>250 \mathrm{~nm} />380 \mathrm{~nm}$, representing humic acid-like substances. FEEM within Region 5 had an Ex/Em range of $>250 />380 \mathrm{~nm}$ for six months, indicating that the natural organic matter in raw water samples could be classified as humic acid. These values are consistent with the SUVA values of raw water containing aromatic organic compounds and suggest that the raw water profile was not affected by seasonal variation.

The TTHMs in the water supply system in Chiang Mai, Thailand, are reported in Figure 7 and the correlation between TTHMs and surrogate parameters (DOC, UV254 and SUVA) are showed in Figure S3 of the Supplementary Materials. Substantial amounts of THMs were formed after chlorine dioxide disinfection. Four DBP species were detected in the water distribution system, namely, CF, BDCM, DBCM, and BF. The concentration of each THM species for rainy and dry seasons were as follows: $\mathrm{CF}$ $(0.00-82.09 \mu \mathrm{g} / \mathrm{L}), \mathrm{BDCM}(0.00-70.62 \mu \mathrm{g} / \mathrm{L}), \mathrm{DBCM}(0.00-6.83 \mu \mathrm{g} / \mathrm{L}), \mathrm{BF}(0.00-14.34 \mu \mathrm{g} / \mathrm{L})$ and CF $(10.98-84.27 \mu \mathrm{g} / \mathrm{L})$, BDCM $(0.00-87.12 \mu \mathrm{g} / \mathrm{L}), \mathrm{DBCM}(0.00-8.71 \mu \mathrm{g} / \mathrm{L})$, and BF $(0.00-14.37 \mu \mathrm{g} / \mathrm{L})$. CF was the predominant species in this study. Interestingly, the raw water sample obtained from a surface water reservoir contained some DPBs that may have occurred naturally. Since the SUVA value of raw water is $>2 \mathrm{~L} / \mathrm{mg} \cdot \mathrm{m}$, organic compounds are dominated by the double-bond group. These substances, precursors for DBPs (including THMs), are produced by a reaction with chlorine during the disinfection processes. The TTHM concentration was generally lower than the water standard after undergoing the sedimentation process. However, the concentration of TTHMs increased after the chlorination process due to a reaction between $\mathrm{ClO}_{2}$ and organic matter. When seasonal effects were compared to the concentration of TTHMs in raw water, we found no significant correlation for either season $(p>0.01)$. When the relevance of average $\mathrm{pH}$ in raw water was considered, the average $\mathrm{pH}$ of 7.6 during the rainy season was comparable to the average $\mathrm{pH}$ of 7.8 during the dry season. Although the average $\mathrm{pH}$ for both seasons did not change dramatically, the $\mathrm{pH}$ was slightly different at six months, possibly while forming TTHMs. The highest $\mathrm{pH}$ during the rainy season was 8.5 in September, followed by 7.8 
and 6.6 in October and November, respectively. The TTHM concentrations also increased during these months, with values of $61.75,35.10$, and $0.00 \mu \mathrm{g} / \mathrm{L}$, respectively. The higher $\mathrm{pH}$ level in September may be due to the month's increased rainfall rate compared with October and November, resulting in enhanced conditions for bacterial and algal growth in the source water. Water containing high amounts of algae and bacteria releases $\mathrm{OH}-$ from algal photosynthesis in the water source, causing the $\mathrm{pH}$ to increase and create additional TTHMs [36]. Conversely, the dry season's highest $\mathrm{pH}$ levels were in January and February (8.1 and 8.7, respectively), whereas in December, it was 6.6. The high $\mathrm{pH}$ in dry seasons may have originated from eutrophication. The TTHM concentrations of 10.98, 24.37, and $22.31 \mathrm{~g} / \mathrm{L}$ were related to $\mathrm{pH}$ values in December, January, and February, respectively. All the water samples in this study contain high values of humic acid; therefore, the formation of THM groups, especially $\mathrm{CF}$, depends on the $\mathrm{pH}$ effect. The formation of TTHMs increases when water bodies have a $\mathrm{pH}$ of 8 or above [37]. Therefore, TTHMs and $\mathrm{pH}$ simultaneously increase when presented with humic substances in raw water. Considering the distance from the water supply point to another point (sampling points 5-7), we found that the concentration of TTHMs in the system decreased as the distance increased due to the degradation of TTHMs. Finally, regarding health concerns, the sum of the ratios of TTHMs from the WHO Guidelines Values (GVs) was greater than one at the distribution point (S5-S7), indicating that the water supply was safe for consumption.

\section{Conclusions}

In this study, we tested the efficiency of the water supply system in an educational institute located in Chiang Mai Province, Thailand. Our results showed that the FEEM values were in the range of $>250 />380 \mathrm{~nm}$ and the SUVA value was $>2 \mathrm{~L} / \mathrm{mg} \cdot \mathrm{m}$. We assumed that the raw water sample had aromatic hydrocarbons (humic acid) from organic matter. In addition, the DOC value decreased by $58.09 \%$. The UV-254 absorbance decreased the most, by $74.63 \%$. Four types of THMs were found after adding disinfectants during the disinfection process: CF, BDCM, DBCM, and BF. CF was the predominant species in this study. Additionally, TTHMs discovered in the water at sampling point 1 (surface water) may have occurred naturally. We found a decrease in the amount of TTHMs as the water underwent coagulation and flocculation processes. We observed that seasonal changes did not affect the incidence of TTHMs in raw water, whereas $\mathrm{pH}$ plays an important role in determining the type and amount of DBPs formed. Overall, the treated water is safe for consumption following the Guideline Values (GVs < 1.0).

Supplementary Materials: The following are available online at https:/ / www.mdpi.com/article/ 10.3390/ijerph18179066/s1, Table S1: Water quality parameters at sampling point, Table S2: Water quality parameters at sampling point, Figure S1, Correlation between UV-254 and DOC (a) and SUVA and DOC (b) in raw water (surface water), Figure S2: The concentration of THMs species $(\mu \mathrm{g} / \mathrm{L})$; (a) Concentration of CF, (b) Concentration of BDCM, (c) Concentration of DBCM and (d) Concentration of BF., and Figure S3. Correlation between concentration of TTHMs and DOC (a), concentration of TTHMs and UV-254 (b), and concentration of TTHMs and SUVA in raw water (surface water).

Author Contributions: Conceptualization, E.K. and A.W.; methodology, S.S.; software, S.S.; validation, E.K., A.W., A.S., and P.R.; formal analysis, S.S.; investigation, S.S. and A.W.; data curation, S.S.; writing—original draft preparation, S.S.; writing—review and editing, A.W., P.I., A.S., C.P., S.W., and S.S.; supervision, E.K., P.R., and A.W. All authors have read and agreed to the published version of the manuscript.

Funding: Center of Excellence on Hazardous Substance Management (HSM) and Faculty of Engineering, Chiang Mai University.

Institutional Review Board Statement: Not applicable.

Informed Consent Statement: Not applicable.

Data Availability Statement: Not applicable. 
Acknowledgments: The authors thank the Office of Higher Education Commission (OHEC) and the S\&T Postgraduate Education and Research Development Office (PERDO), Thailand for support this work. Additionally, this work was supported by Faculty of Engineering, Chiang Mai University. The authors also thank the Research Center in Bioresources for Agriculture, Industry and Medicine, Chiang Mai University. Warm thanks are also extended to the Graduate School, Chiang Mai University. We would like to express our sincere gratitude to Department of Environmental Engineering, Faculty of Engineering, Chiang Mai University, and the Center of Excellence on Hazardous Substance Management (HSM) for invaluable supports in terms of facilities and scientific equipment.

Conflicts of Interest: The authors declare no conflict of interest.

\section{References}

1. The Population in Thailand. Available online: https://stat.bora.dopa.go.th (accessed on 12 August 2021).

2. The Quantity of Production Water in Thailand. Available online: https://www.mwa.co.th (accessed on 12 August 2021).

3. James, E.; American Water Works Association. Water Quality E Treatment: A Handbook on Drinking Water, 6th ed.; McGraw Hill Education: New York, NY, USA, 2011.

4. Leenheer, J.A.; Croué, J.-P. Peer Reviewed: Characterizing Aquatic Dissolved Organic Matter. Environ. Sci. Technol. 2003, 37, 18A-26A. [CrossRef]

5. World Health Organization. Guidelines for Drinking-Water Quality, 4th ed.; World Health Organization: Geneva, Switzerland, 2011.

6. Loper, J.C.; Lang, D.R.; Schoeny, R.S.; Richmond, B.B.; Gallagher, P.M.; Smith, C.C. Residue organic mixtures from drinking water show in vitro mutagenic and transforming activity. J. Toxicol. Environ. Health 1978, 4, 919-938. [CrossRef] [PubMed]

7. Zhang, L.; Xu, L.; Zeng, Q.; Zhang, S.H.; Xie, H.; Liu, A.L.; Lu, W.Q. Comparison of DNA damage in human-derived he-patoma line (HepG2) exposed to the fifteen drinking water disinfection byproducts using the single cell gel electrophoresis assay. Mutat. Res. 2011, 741, 89-94. [CrossRef]

8. Richardson, S.D.; Plewa, M.J.; Wagner, E.D.; Schoeny, R.; DeMarini, D. Occurrence, genotoxicity, and carcinogenicity of regulated and emerging disinfection by-products in drinking water: A review and roadmap for research. Mutat. Res. Mutat. Res. 2007, 636, 178-242. [CrossRef] [PubMed]

9. Plewa, M.J.; Muellner, M.G.; Richardson, S.D.; Fasano, F.; Buettner, K.M.; Woo, Y.-T.; McKague, A.B.; Wagner, E.D. Occurrence, Synthesis, and Mammalian Cell Cytotoxicity and Genotoxicity of Haloacetamides: An Emerging Class of Nitrogenous Drinking Water Disinfection Byproducts. Environ. Sci. Technol. 2007, 42, 955-961. [CrossRef]

10. Six Year Review 3 Technical Support Document for Disinfectants/Disinfection Byproducts Rules. Available online: https: //www.epa.gov/sites/production/files/2016-12/documents/810r16012.pdf (accessed on 8 March 2020).

11. Rahman, B.; Cowie, C.; Driscoll, T.; Summerhayes, R.J.; Armstrong, B.K.; Clements, M.S. Colon and rectal cancer incidence and water trihalomethane concentrations in New South Wales, Australia. BMC Cancer 2014, 14, 445. [CrossRef] [PubMed]

12. Lin, H.; Dai, Q.; Zheng, L.; Hong, H.; Deng, W.; Wu, F. Radial basis function artificial neural network able to accurately predict disinfection by-product levels in tap water: Taking haloacetic acids as a case study. Chemosphere 2020, 248, 125999. [CrossRef] [PubMed]

13. Beane Freeman, L.E.; Cantor, K.P.; Baris, D.; Nuckols, J.R.; Johnson, A.; Colt, J.S.; Schwenn, M.; Ward, M.H.; Lubin, J.H.; Waddell, R.; et al. Bladder cancer and water disinfection by-product exposures through multiple routes: A popu-lation-based case-control study (New England, USA). Environ. Health Persp. 2017, 125, 067010. [CrossRef] [PubMed]

14. Villanueva, C.; Cantor, K.P.; Grimalt, J.; Malats, N.; Silverman, D.; Tardon, A.; Garcia-Closas, R.; Serra, C.; Carrato, A.; CastañoVinyals, G.; et al. Bladder Cancer and Exposure to Water Disinfection By-Products through Ingestion, Bathing, Showering, and Swimming in Pools. Am. J. Epidemiol. 2006, 165, 148-156. [CrossRef] [PubMed]

15. Ackerson, N.O.B.; Liberatore, H.; Plewa, M.J.; Richardson, S.D.; Ternes, T.A.; Duirk, S.E. Disinfection byproducts and halogenspecific total organic halogen speciation in chlorinated source waters-The impact of iopamidol and bromide. J. Environ. Sci. 2019, 89, 90-101. [CrossRef] [PubMed]

16. Tugulea, A.-M.; Aranda-Rodriguez, R.; Bérubé, D.; Giddings, M.; Lemieux, F.; Hnatiw, J.; Dabeka, L.; Breton, F. The influence of precursors and treatment process on the formation of Iodo-THMs in Canadian drinking water. Water Res. 2018, 130, $215-223$. [CrossRef] [PubMed]

17. Hong, H.; Yan, X.; Song, X.; Qin, Y.; Sun, H.; Lin, H.; Chen, J.; Liang, Y. Bromine incorporation into five DBP classes upon chlorination of water with extremely low SUVA values. Sci. Total. Environ. 2017, 590-591, 720-728. [CrossRef] [PubMed]

18. Chu, W.; Gao, N.; Yin, D.; Krasner, S.W. Formation and speciation of nine haloacetamides, an emerging class of nitrogenous DBPs, during chlorination or chloramination. J. Hazard. Mater. 2013, 260, 806-812. [CrossRef] [PubMed]

19. Yang, X.; Guo, W.; Lee, W. Formation of disinfection byproducts upon chlorine dioxide preoxidation followed by chlo-rination or chloramination of natural organic matter. Chemosphere 2013, 91, 1477-1485. [CrossRef]

20. Bond, T.; Huang, J.; Graham, N.J.; Templeton, M.R. Examining the Interrelationship between DOC, Bromide and Chlorine Dose on DBP Formation in Drinking Water-A Case Study. Sci. Total. Environ. 2014, 470-471, 469-479. [CrossRef]

21. Yang, M.; Zhang, X. Comparative Developmental Toxicity of New Aromatic Halogenated DBPs in a Chlorinated Saline Sewage Effluent to the Marine PolychaetePlatynereis dumerilii. Environ. Sci. Technol. 2013, 47, 10868-10876. [CrossRef] 
22. Richardson, S.D.; Thruston, A.D.; Caughran, T.V.; Chen, P.H.; Collette, T.W.; Floyd, T.L.; Schenck, K.M.; Lykins, B.W.; Sun, G.; Majetich, G. Identification of New Drinking Water Disinfection by_Products from Ozone, Chlorine Dioxide, Chloramine, and Chlorine. Water Air Soil Pollut. 2000, 123, 95-102. [CrossRef]

23. Korn, C.; Andrews, R.C.; Escobar, M.D. Development of chlorine dioxide-related by-product models for drinking water treatment. Water Res. 2002, 36, 330-342. [CrossRef]

24. Schmidt, W. Using Chlorine Dioxide for Drinking Water Disinfection by the Application of the Chlorite/Chlorine Process. Acta Hydrochim. Hydrobiol. 2004, 32, 48-60. [CrossRef]

25. Ratpukdi, T.; Sinorak, S.; Kiattisaksiri, P.; Punyapalakul, P.; Siripattanakul-Ratpukdi, S. Occurrence of trihalomethanes and haloacetonitriles in water distribution networks of Khon Kaen Municipality, Thailand. Water Supply 2019, 19, $1748-1757$. [CrossRef]

26. Chiang Mai University Map. Available online: https:/ / moovitapp.com (accessed on 8 March 2020).

27. APHA; AWWA; WPCF. Standard Methods for the Examination of Water and Wastewater, 22nd ed.; American Water Works Association: Washington, DC, USA, 2012.

28. USEPA Method 551.1. In Determination of Chlorination Disinfection Byproducts, Chlorinated Solvents and Halogenated Pesticides/Herbicides in Drinking Water by Liquid-Liquid Extraction and Gas Chromotography with Electron Capture Detection; Revision 1.0; U.S. Environmental Protection Agency, Office of Research and Development, National Exposure Research Laboratory: Cincinnati, OH, USA, 1995.

29. Tungsudjawong, K.; Leungprasert, S.; Peansawang, P. Investigation of humic acids concentration in different seasons in a raw water canal, Bangkok, Thailand. Water Supply 2017, 18, 1727-1738. [CrossRef]

30. Yan, M.; Wang, D.; Ni, J.; Qu, J.; Chow, C.; Liu, H. Mechanism of natural organic matter removal by polyaluminum chloride: Effect of coagulant particle size and hydrolysis kinetics. Water Res. 2008, 42, 3361-3370. [CrossRef] [PubMed]

31. Yan, M.; Wang, D.; Ni, J.; Qu, J.; Ni, W.; van Leeuwen, J. Natural organic matter (NOM) removal in a typical North-China water plant by enhanced coagulation: Targets and techniques. Sep. Purif. Technol. 2009, 68, 320-327. [CrossRef]

32. Wang, D.; Hu, Q.-Y.; Li, M.; Wang, C.; Ji, M. Evaluating the removal of organic fraction of commingled chemical industrial wastewater by activated sludge process augmented with powdered activated carbon. Arab. J. Chem. 2016, 9, S1951-S1961. [CrossRef]

33. American Water Works Association. Characterization of Natural Organic Matter and Its Relationship to Treatability, 1st ed.; AWWARF and AWWA: Washington, DC, USA, 1993.

34. Eaton, A. Measuring UV-absorbing organics: A standard method. J. Am. Water Work. Assoc. 1995, 87, 86-90. [CrossRef]

35. Chen, W.; Westerhoff, P.; Leenheer, J.A.; Booksh, K. Fluorescence Excitation-Emission Matrix Regional Integration to Quantify Spectra for Dissolved Organic Matter. Environ. Sci. Technol. 2003, 37, 5701-5710. [CrossRef]

36. Zhou, X.; Zheng, L.; Chen, S.; Du, H.; Raphael, B.M.G.; Song, Q.; Wu, F.; Chen, J.; Lin, H.; Hong, H. Factors influencing DBPs occurrence in tap water of Jinhua Region in Zhejiang Province, China. Ecotoxicol. Environ. Saf. 2019, 171, 813-822. [CrossRef]

37. Hung, Y.-C.; Waters, B.W.; Yemmireddy, V.K.; Huang, C.-H. pH effect on the formation of THM and HAA disinfection byproducts and potential control strategies for food processing. J. Integr. Agric. 2017, 16, 2914-2923. [CrossRef] 